\title{
Project LifeLab Food and Health - Innovative Teaching for the Future: Development of Student Active Learning Tasks for Home Economics Education in the $21^{\text {st }}$ Century
}

Cecilie Beinert ${ }^{\star 1}$, Nina Cecilie Øverby ${ }^{2}$ And Frøydis Nordgård ViK ${ }^{2}$

$\approx$ Food and Health, previously referred to as Home Economics, is a mandatory school subject in Norway. It has the unique advantage of giving all students, regardless of their social background, practical skills and knowledge, life skills that are important for their future health. In the LifeLab Food and Health project, we have developed a research-based and innovative teaching programme and evaluated how it is perceived in a school setting in Norway. This teaching programme is for use in Food and Health teacher education, but also in the education of primary and lower secondary school students in the same subject. LifeLab Food and Health consists of learning tasks in which students in the sixth and ninth grades in school gain first-hand knowledge and an understanding of life skills that are important to manage everyday life. In this paper, we present the learning activities developed and how the students experienced them. Examples of such learning tasks are tasks revealing the science behind dietary guidelines and the promotion of a healthy diet through student active tasks. Our aim is to establish LifeLab Food and Health as a "best practice" within master's education in Home Economics at the University of Agder in Norway.

Keywords: home economics, food and health, active learning tasks, life skills, school

$1 \quad{ }^{\star}$ Corresponding Author. Department of Nutrition and Public Health, University of Agder, Norway; cecilie.beinert@uia.no.

2 Department of Nutrition and Public Health, University of Agder, Norway. 


\section{Projekt LifeLab prehrana in zdravje - inovativno poučevanje za prihodnost: razvoj aktivnih učnih nalog za učence pri pouku gospodinjstva v 21. stoletju}

Cecilie Beinert, Nina Cecilie Øverby in Frøydis Nordgård Vik

$\approx$ Predmet prehrana in zdravje, prej imenovan gospodinjstvo, je na Norveškem obvezni šolski predmet. Njegova edinstvena prednost je, da vsem učencem, ne glede na njihovo socialno ozadje, omogoča pridobivanje praktičnih spretnosti in znanja, življenjskih veščin, ki so pomembne za njihovo zdravje v prihodnosti. V okviru projekta LifeLab Food and Health (slov. LifeLab prehrana in zdravje) smo razvili na raziskavah temelječ in inovativen učni program ter ocenili, kako ga dojemajo $\mathrm{v}$ šolskem okolju na Norveškem. Učni program je namenjen uporabi pri izobraževanju učiteljev na področju prehrane in zdravja pa tudi pri izobraževanju osnovnošolcev in dijakov nižjih razredov srednjih šol pri istem predmetu. Projekt LifeLab prehrana in zdravje je sestavljen iz učnih nalog, pri katerih učenci v šestem in devetem razredu iz prve roke pridobivajo znanje in razumevanje življenjskih veščin, ki so pomembne za obvladovanje vsakdanjega življenja. V tem prispevku predstavljamo razvite učne naloge in kako so jih učenci doživljali. Primera takih učnih nalog sta nalogi, ki razkrivata znanstveno ozadje prehranskih smernic in spodbujanje zdrave prehrane $z$ aktivnimi nalogami učencev. Naš cilj je vzpostaviti oblike dela, razvite v okviru projekta LifeLab prehrana in zdravje, kot »najboljšo prakso« v okviru magistrskega izobraževanja na področju gospodinjstva na Univerzi Agder na Norveškem.

Ključne besede: gospodinjstvo, prehrana in zdravje, aktivne učne naloge, življenjske veščine, šola 


\section{Introduction}

Data from the Global Burden of Disease (GBD) study (Afshin et al., 2019) reveals the essential role food and nutrition play in human health. Globally, the intake of healthy foods and nutrients is suboptimal, while the intake of unhealthy foods and nutrients is higher than the desired amount. Most of the disease burden related to diet is a result of a too low intake of whole grains and fruit, and a high intake of sodium (Afshin et al., 2019).

Although the diet of children and adolescents in Norway is largely in accordance with the dietary guidelines set by the health authorities (Hansen Brooke et al., 2016), both groups still consume too little fruit, vegetables and fish, and too much saturated fat, salt and sugar (Hansen Brooke et al., 2016). Since dietary habits track into adulthood (Craigie et al., 2011; Cruz et al., 2018), establishing healthy habits early in life is important. Targeting children and adolescents has therefore been a political priority nationally (Ministry of Health and Care Services, 2017) and internationally (World Health Organization, 2006, 2015). A national action plan for a healthier diet was published in 2017 in Norway, presenting several dietary targets for change among children and adolescents by the year 2021 (Ministry of Health and Care Services, 2017). The World Health Organization (WHO) has provided recommendations on ways to target this age group. It advocates improving education on healthier food choices by educating children in nutrition and a healthy lifestyle (European Commission, 2014), as well as including awareness-raising activities and practical cooking lessons in school.

In Norway, the subject Food and Health (FH) (previously referred to as Home Economics) is mandatory in primary and lower secondary school (Directorate for Education and Training, 2019b). Although there are competency aims after the seventh and tenth grades, most of the teaching is clustered in the sixth and ninth grades. FH should promote public health, food enjoyment and interest in the diversity of foods and food habits in society. It is crucial for students to develop an understanding of how diet and health are intertwined. They should also develop critical thinking, ethical awareness and a sense of responsibility, so that they are able to choose foods that are both health promoting and sustainable (Directorate for Education and Training, 2019b). This ambitious curriculum reaches all students, regardless of their socioeconomic position, and is thus an important element in public health work. In Norway, $96 \%$ of all students attend public schools (Statistics Norway, 2020). Thus, public schools are considered a health-promoting arena of great importance. An example of the student competence aims in FH after the seventh grade is to "use 
food labelling and diet models to put together a healthy, varied and sustainable diet and reflect on their choices", while after the tenth grade students should be able to "use their senses to assess the quality of food, explore and combine flavours in cooking, and improve recipes, menus and serving of food" (author's translation) (Directorate for Education and Training, 2019b).

Although the literature on how FH is taught in Norwegian schools is scarce, research suggests that there is a strong focus on developing students' practical cooking skills in FH education (Beinert et al., 2020; Espeland et al., 2013; Veka et al., 2018), which has been central since the introduction of the subject more than a hundred years ago, when it was called "school kitchen" (Askeland et al., 2017). The traditional teacher-led approach to FH education, whereby the students cook according to a set of recipes based on foods that the teachers have purchased in advance, still characterises todays teaching (Beinert et al., 2020; Espeland et al., 2013; Veka et al., 2018). Students' ability to follow recipes while cooking is highlighted as important according to FH teachers (Espeland et al., 2013). Consequently, the development of students' ability to think critically, be creative and understand how food impacts our health and environment may not be fully developed. Moreover, comprehensive approaches to food and nutrition education, including both theory and practical cooking, may have a stronger impact on students' dietary choices and thus on the health outcome (Burton et al., 2018; Grosso et al., 2013). Today, theory and practice do not seem to go fully hand-in-hand (Lassen, 2020) and the subject does not seem to enhance students' knowledge and attitudes, as foreseen by the curriculum (Øvrebø, 2014). Therefore, FH education needs to better integrate theory into practical learning activities (Øvrebø, 2014) and focus more on cognitive-oriented learning tasks that enable students to engage with theory in a meaningful and engaging way (Taar, 2017).

Based on the challenges of FH in Norway today, the LifeLab Food and Health (FH) project was initiated in 2017. We were inspired by LifeLab in the UK; specifically, by our colleagues at the University of Southampton, who have initiated a LifeLab to educate young people for lifelong health. LifeLab in Southampton is a unique, state-of-the art teaching laboratory dedicated to improving adolescent health by giving school students opportunities to learn first-hand the science behind health messages (Woods-Townsend et al., 2015). LifeLab in the UK was initiated in 2008 and is a collaboration between the University of Southampton, Southampton General Hospital and the city. Although LifeLab in the UK is centred around the school subject of science, we decided to focus our modified, Norwegian version of LifeLab on FH education. Named LifeLab FH, the project aimed to develop and evaluate a research-based and 
innovative teaching programme, a LifeLab, to be used in the education of schoolteachers in FH and for school students in the same subject. We developed several state-of-the-art student active learning tasks in which students and future FH teachers can engage with research in an easy and specific way through practical assignments, enabling them to learn the science behind health messages in order to enhance lifelong health. This way, the connection between the intake of healthy foods and the students' own health is more evident, whereby LifeLab FH aims to present a modern approach to FH education both in schools and universities as an example of the Home Economics education needed for the $21^{\text {st }}$ century. By including and linking relevant theory to practical work in $\mathrm{FH}$ lessons, we aim to provide students with a stronger basis for learning. The objective of the current paper is to present an overview of the LifeLab FH teaching programme, i.e., the different student active learning tasks that focus on the theoretical content of the FH curriculum in Norway, as well as to present experiences from the first evaluations of these tasks in schools.

\section{Method}

\section{Development of the learning tasks}

In order to develop learning tasks that are relevant and interesting for the users, we invited different relevant stakeholders to participate in the project.

First, Focus Group Discussions (FGDs) with FH teachers and students were conducted at three local schools to gain an insight into what kind of learning tasks they would value the most and would find most appropriate for FH. The feedback obtained was then used as a basis for the development of the learning tasks in the LifeLab FH project. The main feedback from both students and teachers was the importance of active learning tasks that engage the students, as they believe that this is important for their learning outcome (Beinert et al., 2020). Teachers also emphasised that it is important for the learning tasks to be easy to use and readily adaptable to their teaching. In addition to the findings from these FGDs, the FH curriculum and relevant white papers on future competencies to be developed in school were used as a basis for the development of the learning tasks.

After the FGDs were conducted, the learning tasks were developed through workshops with two teacher education students specialising in $\mathrm{FH}$ at the University of Agder (UiA), an FH teacher, a scientific assistant, a master's student, and the PhD student who had led the workshops and the developmental work. The learning tasks were aimed at students in primary and lower secondary 
school, as well as students specialising in FH in their teacher education. By being introduced to these learning tasks during their university studies, the latter group can implement the ideas in schools when they start working as school teachers.

So far, six student active learning tasks have been developed, emphasising fruit and vegetable intake, food labelling, the nutritional value of foods and different nutritional claims. As dialogue, argumentation and collaboration are important in social learning and development (Directorate for Education and Training, 2019a), and given that oral skills are one of the four basic skills to be developed in all subjects in school (Directorate for Education and Training, 2019b), we adopted a sociocultural approach to learning (Vygotsky, 1978) when developing the learning tasks. This shares ideas with $21^{\text {st }}$ century learning, which acknowledges the social nature of learning, whereby learning "is understood to be importantly shaped by the context in which it is situated and actively constructed through social negotiation with others" (Dumont et al., 2012, p. 3). Moreover, skills in problem solving, communication and collaboration are highlighted as important in $21^{\text {st }}$ century learning (Kay, 2015). For more details on the development and the pedagogical basis of the learning tasks, please see Beinert (2021) and Beinert et al. (2021).

The learning tasks were tested at two of the three local schools included in the project. The test groups consisted of three groups of sixth graders and four groups of ninth graders (79 students in total) and the learning tasks were conducted in one of the students' scheduled FH classes (approximately two school hours). However, due to the extent of the project, we were only able to analyse grade six, consisting of one class of 13 students, and two other classes with 15 students in each class, i.e., 43 students in total (Beinert et al., 2021). Audio and video recordings were used to evaluate how the learning tasks worked. The students worked in groups of three or four, with one wide-angle camera placed at each group of students, which captured student talk and both verbal and non-verbal interaction throughout the class. One of the teacher students and two other participants in the initial workshop (one scientific assistant and one master's student in public health) conducted the teaching, while the researcher (the PhD student) passively observed the classroom. The FH teacher had received a description of the learning tasks and all of the necessary material in advance and was invited to participate as much as s/he wanted. The learning tasks were similar for both levels, with minor adjustments in difficulty. After the class, a short FGD was conducted to explore how both the students and the teachers experienced the class. 


\section{Results}

\section{Description and evaluation of the learning tasks}

The overall theme of the LifeLab FH learning tasks was food choices, and the analysis and findings of the evaluation of three of the six tasks can be found elsewhere (Beinert et al., 2021).

\section{Learning Task 1}

In the first learning task, the students ranked pictures of different dishes or food items from the most to the least nutritious. They worked in groups of three or four to facilitate cooperation and collaboration in solving the different tasks. See Figure 1 for illustration.

\section{Figure 1}

Placement of students and camera (for evaluation purposes) during the class

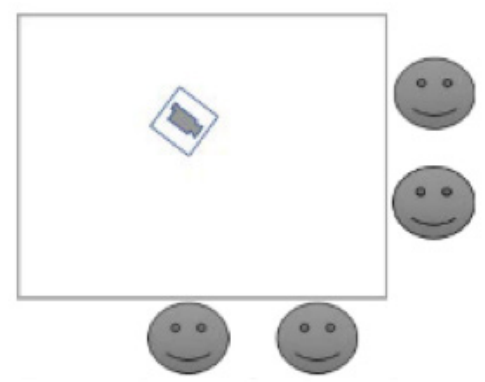

Note. Adapted from Beinert et al., 2021.

Each group of students was given eight pictures of different food items. The items (Table 1) were common breakfast/lunch items assumed to be familiar to most students. 


\section{Table 1}

Pictures included in the picture ranking activity

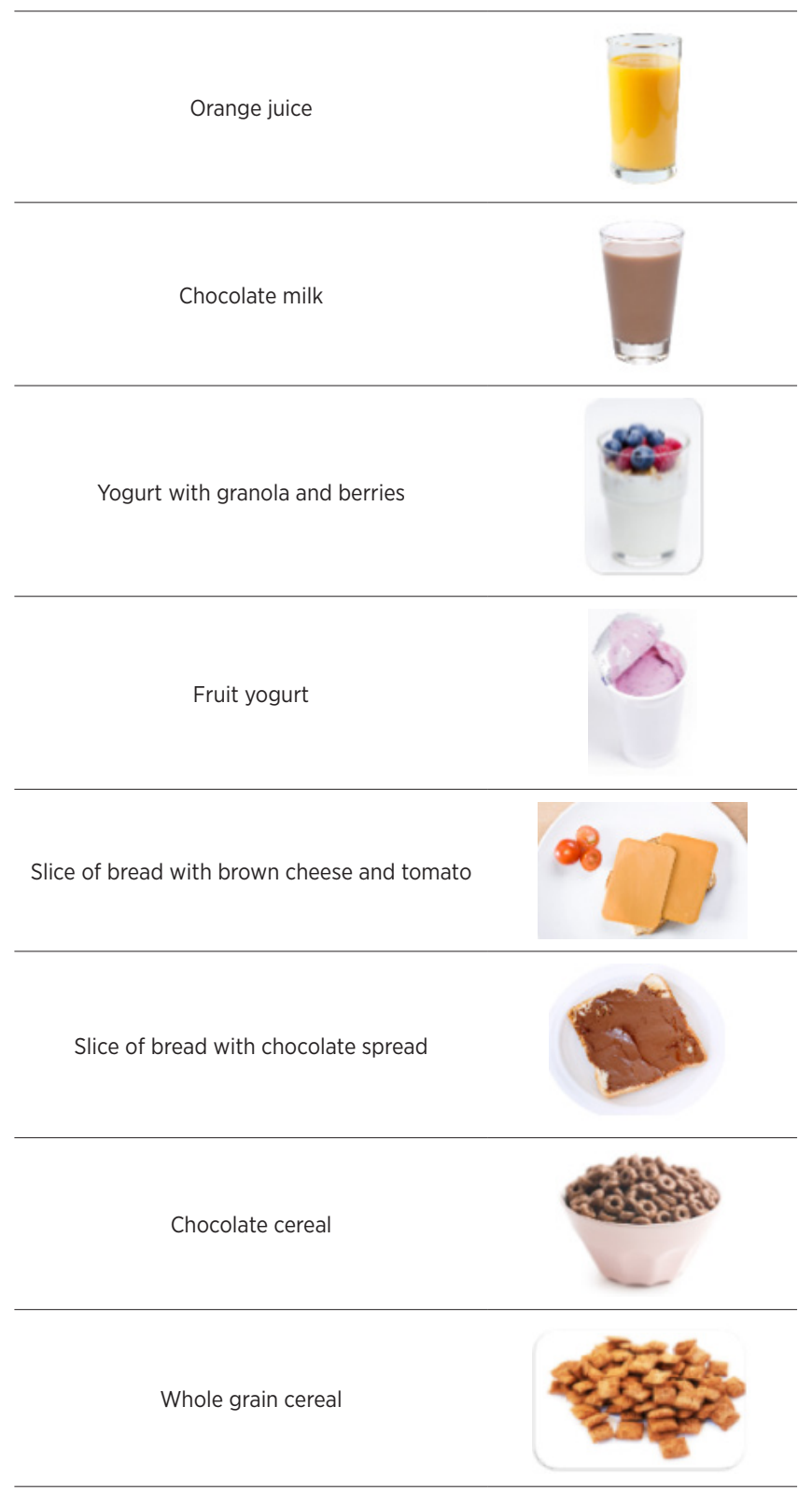

Note. Adapted from Beinert et al., 2021. 
The students were encouraged to share their thoughts and knowledge within the group and collaboratively reach agreement on how to rank the different items. After all of the groups had agreed on an order, the teacher tried to arrange them on the whiteboard in plenary based on input from the students and additional facts provided by the teacher regarding which food groups the items belong to (e.g., berries, dairy products, etc.) and the nutrients they contain. At the sixth-grade level, the students were generally very active in this discussion and widely shared their thoughts. In the ninth grade, however, the students were not as active in participating in the exchange of thoughts and the teachers had to do most of the talking. Our experience was that only a few students in each class willingly spoke out.

When working on arranging the pictures, some of the students were very confident about the right answer and therefore solved the task quickly. Many of the students merely based their arrangement on sugar content. Prior to the task, some of the students had viewed a short video on sugar content in certain beverages and measured sugar content in products similar to those they were asked to arrange, which may explain why they used sugar as a premise when arranging the pictures.

In this task, the students were challenged in the skill of discussing and using each other's knowledge to come to an agreement. In some of the groups, one or two of the students were nevertheless more in charge and did most of the talking when arranging of the pictures, leaving the others more passive. In other groups, however, all of the students participated, shared their knowledge, and came to a shared agreement on an order. All of the groups managed to come to an agreement, but the groups ordered their pictures differently. Some struggled to arrange the pictures, while others found it easy and hence finished quickly. When the teachers tried to rank the items on the whiteboard, the challenge of ranking one item over another, with a right and wrong answer, was highlighted. Although the ranking of some of the items - such as determining that chocolate cereal is less nutritious than whole grain cereal - was fairly obvious, most of the other items were more difficult to arrange. The aim was for the students to understand that it is not a simple task to rank such different items, and for them to gain more knowledge of the nutritional value each individual item. This knowledge was then used as a basis by the teacher in ranking the pictures in plenary. 


\section{Learning Task 2}

In Learning Task 2, two different loaves of bread with different whole grain content were presented to the students, both of which were cut in half so that the students could examine them on the inside and the outside. The students then identified the whole grain content of the two loaves of bread without seeing the packaging/food label. In Norway, a food labelling system is used called the Bread Scale (Figure 2), which illustrates the whole grain content of bread and other bakery products.

\section{Figure 2}

Bread Scale. Each section (red) presents the percentage of whole grain in the product

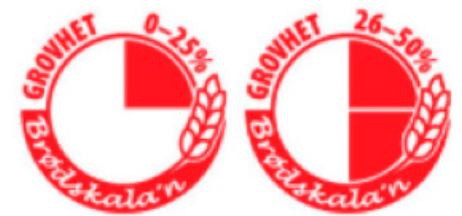

Note. Adapted from matportalen.no.
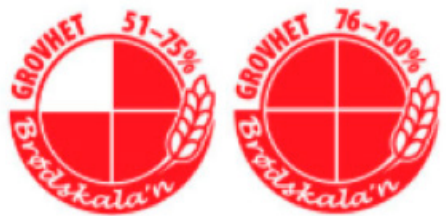

The teacher presented one loaf of bread at a time for the students to examine, after which the students placed them in a continuum, from extra whole grain to white bread with very little whole grain content. The teacher then showed the students the packaging with the correct icon of whole grain content. Finally, the teacher elaborated on whole grains, relating them to nutritional recommendations and about food labelling together with the students.

During the evaluation of this learning task, one loaf of bread qualified for the $0-25 \%$ icon and the other for the $76-100 \%$ icon. Moreover, the whole grain bread was pale in colour and had no visible grains, while the white bread was darker and had visible grains on top. This was to illustrate the purpose of food labelling, as it is not easy to judge the whole grain content of a type of bread merely by looking at it. During this task, the teacher asked the students if they knew which loaf of bread it was recommended to eat and why, thus enabling them to repeat the national dietary guidelines regarding such products.

The students were surprised to see the level of whole grain content in the two loaves of bread. Most of them used the colour or the number of visible grains of the loaf of bread to judge its whole grain content and thus guessed wrong. They then realised that one cannot know the whole grain content of a loaf of bread just by looking at it. Some bread that is light in colour could in fact have high whole grain content and vice versa. This way, the students saw the value of such food labels. 


\section{Learning Task 3}

In this task, the students identified the sugar content of different items. They were given the packaging of different items (yoghurts and cereals with different sugar and fibre content, chocolate spread, and a Norwegian spread called "prim", a sweetened spread made of whey from cows' milk). After the teacher demonstrated how to find the sugar content of a given portion size, the students were encouraged to do so themselves within their groups. They could therefore use their mathematics skills to see how sugar content varied between the products, thus helping them see the connections between school subjects, in this case FH and mathematics. Although the students measured the sugar content for one portion (e.g., 125g of yogurt), some of them believed it was the content of the whole item, so this had to be specified for them. Furthermore, the fact that the portion size on the packaging is often small was illustrated to the students by showing them how much $15 \mathrm{~g}$ of chocolate spread (which is equal to one standard portion) really is. The students were quite surprised to see the amount of sugar in one portion of chocolate spread.

\section{Learning Task 4}

This task aimed to illustrate and concretise the "five a day" recommendations for fruit and vegetables from health authorities. A selection of different fruit and vegetables, frozen and fresh, were placed on a tray. The students were then instructed to select the amount they believed equalled "five a day" and then weigh it on a scale. As the students often picked five different fruits and vegetables, they were surprised to see that they had selected more than 500 grams, which is the recommended amount. They were then asked to peal the fruit with thick peal (banana and orange), and then weigh the net, i.e., the amount consumed, which enabled them to see the amount and compare it to the recommendations. The students were also taught that one portion equals one handful, and the portions for children are therefore smaller than for adults.

\section{Learning Task 5}

The fifth task was a simple jigsaw, where the students read a text concerning either food and social media, food and sustainability, nutrition and health, or food choices. They read one text and then summarised the main points to their peers within the group, who had read one of the other texts. This way, the students became each other's teachers. However, some of the students found it challenging to summarise the main points and hence the learning outcome varied between the students. 


\section{Learning Task 6}

At the end of the class, there was a quiz that summarised some of the topics discussed during class (tasks 1-5), making this the sixth LifeLab FH task. In this task, which was called the " 50 game", 25 cards with questions on both sides (50 numbered questions) were distributed around in the classroom. The students first had to agree on a unique sound for their group. Then, one student in each group rolled a die. The groups had to spread out to quickly find the card with the number on the die. When a student found the number, s/he called for the other group members by using the agreed sound. After finding and answering the question, the group then gave the answer to the teacher. If the answer was correct, they rolled the die again and the number rolled was then added to the first number to determine the next card to be found, e.g., if they rolled three then six, they had to find card number nine. The first group to reach 50 won.

The learning tasks engaged the students to different degrees and will undergo further development and improvements. In the FGDs after the class, the students stated that they appreciated the opportunity to be active and solve the tasks themselves, which is in line with the students' expressed preferences from the initial FGDs conducted prior to development (Beinert et al., 2020).

During the class, the teacher only assisted when necessary when the students were working in their groups, as well as leading the discussion with the students in plenary. It was observed that the sixth-grade students were generally more active (raising their hands, sharing their thoughts, etc.) than the ninthgrade students. The "50 game" was especially popular among the sixth graders. The students in both grades nonetheless provided positive feedback about the class. The teachers found the tasks to be relevant and a useful way to work with the theoretical topics. Due to the practical approach to the theory, one teacher mentioned how she believed the students were learning a lot of theory without noticing that they were dealing with theory. The students were used to learning theory through homework or by working with written assignment or lectures if there was any time left at the end of the class (Beinert et al., 2020).

\section{Discussion}

The LifeLab FH project described aimed to develop different student active learning tasks for the Food and Health subject and evaluate how the tasks work in a school setting. The goal was to present a modern approach to $\mathrm{FH}$ education in both schools and universities, that is, an example of the Home Economics education needed for the $21^{\text {st }}$ century.

Overall, both the FH teachers and the students had a positive experience 
with the different learning tasks (Beinert et al., 2021). The students enjoyed having an active role, which was supported by the $\mathrm{FH}$ teachers. The teachers also mentioned how the tasks were relevant and could easily be adapted to different contexts.

In this project, the voices of both students and $\mathrm{FH}$ teachers were considered in the development of the learning tasks, thus making it more likely that the tasks could best meet their needs and increasing the chance of the tasks being adopted by the FH teachers themselves. However, as both teachers' and students' voices were considered, contradictory views regarding what kind of learning tasks are preferred must be considered. In the present study, both teachers and students emphasised that student active learning tasks are important for learning. "Fun" was a word frequently used by the students as an important factor for their motivation and learning (Beinert et al., 2020). The tasks were also described as something practical that they could do by themselves. The teachers also mentioned the importance of learning tasks being engaging and fun for the students in order for them to be successful.

The students in both grades provided positive feedback after performing the tasks. Engaging the ninth graders to the same degree as the sixth graders was nonetheless challenging, and how to adjust the learning tasks to better suit ninth graders should be explored further.

Some of the students lost focus when the teacher did most of the talking, e.g., during the arrangement of the pictures on the whiteboard. To accommodate this will require well-designed learning tasks, motivated students, and teachers who are skilled at facilitating active learning. When our tasks were evaluated in school classes, not all of the "teachers" (the assistants who participated in the development of the activities) were teacher educated, so they were not trained in class management. The practicalities of the learning tasks nonetheless worked well, probably because all of the teachers were familiar with the learning tasks and had time to prepare themselves ahead of the evaluation.

The second learning task with the two loaves of bread could, for example, be used in conjunction with baking bread. Another suggestion could be to include this learning task when the students learn about the nutritional guidelines. One competency aim for students in the sixth grade is (author translation): "to use food labelling and dietary models to compose a healthy, varied and sustainable diet and reflect on one's own choices" (Directorate for Education and Training, 2019b). The second learning task is a concrete example of how to use food labelling to choose healthy foods according to the dietary guidelines, which recommend that whole grain products are included in our diet every day (Norwegian Directorate of Health, 2011). 
Since developing and evaluating these active learning tasks, $\mathrm{FH}$ teacher students at UiA have been introduced to them during their education, in order to inspire them to use such learning tasks in their future careers as FH teachers, as a "best practice" approach. As stated earlier, FH classes in schools today are mostly concerned with cooking, and students get the theoretical topics of the subject as homework or short lectures before, during or after cooking (Beinert et al., 2020). Thus, the FH subject is in need of alternative approaches to the theory if we want students to develop all of the competencies highlighted in the curriculum. By being given an opportunity to work more actively with theoretical aspects like food labelling or sustainability in FH classes, students are better equipped to develop the competencies highlighted in the curriculum and cultivate these important life skills. By including such learning tasks in the education of FH teachers, we believe this could be an example of "best practice" in FH education at universities, as well as in schools via the graduated teachers.

The older students get, the more responsibility they will have for their own diet. Being able to understand the importance of a healthy and varied diet, and being capable of identifying these products in a large food market, are therefore important competencies. Having the knowledge and skills to orient themselves in a complex food landscape, e.g., by understanding food labelling, could provide students with important life skills. We therefore believe that the student active learning tasks developed can complement today's teaching and serve as the kind of Home Economics education needed for the $21^{\text {st }}$ century. As FH teachers in Norway are generally very content with teaching FH and feel they have mastered their teaching to a great extent (Vik et al., 2020), this is a valuable starting point for further development of the subject and for students' learning, as the teacher's self-efficacy can be important for student learning (Fackler \& Malmberg, 2016). Moreover, students generally enjoy FH classes (Beinert et al., 2020; Øvrebø, 2014), which is another important advantage when it comes to promoting knowledge about the connections between food and students' health.

On his reflection after 30 years in the field of Home Economics, Caraher (2019) asks for stronger links to public health nutrition in future Home Economics education. He argues that "the links with public health nutrition need to be strengthened; developments such as food literacy and the emphasis on cooking skills need to be challenged and fitted within a broader scope of Home Economics" (Caraher, 2019, p. 4). Given the strong focus on cooking-related activities during FH classes (Beinert et al., 2020), we need to encourage teachers to think differently in their future teaching, so that all of the competencies highlighted in the curriculum are emphasised. 
Since the first project period of LifeLab FH has ended, the aim is now to make all of the learning tasks available to all FH teachers in Norway. Therefore, the digitising of the different tasks has started, with the aim of making small instructional videos that will be published online free of charge. In the future, all $\mathrm{FH}$ teachers will therefore have access to the learning tasks, and they can thus be implemented nationally.

\section{Conclusion}

As previous research suggests that the traditional practice of $\mathrm{FH}$ education is evident in Norwegian schools, we argue that it is time for a renewal. By including active learning tasks such as those developed in the LifeLab FH project, we can strengthen current teaching practices so that they become the kind of Home Economics education needed in the $21^{\text {st }}$ century. This way, students are given the opportunity to work more actively with theoretical topics of the curriculum, building important life skills. The LifeLab FH learning tasks may therefore complement current teaching practices and may be considered as "best practice" in FH education. By shifting the focus from a teacher-centred approach to learning to a more student-centred approach, teachers will facilitate a learning environment more in line with $21^{\text {st }}$ century learning. Moreover, focusing more strongly on awareness-raising activities and food choices in teaching $\mathrm{FH}$ is more in line with the recommendations proposed by the European Commission. The learning tasks developed and evaluated in the present project received generally positive feedback from both students and teachers, mainly because they were designed as practical learning tasks targeting more theoretical content. However, only a limited number of students and teachers were included in the project, and the research concerning FH education is limited. Therefore, more research is needed on how we can develop FH as a futureoriented subject in which students develop critical thinking skills and are able to choose foods that are health promoting and sustainable. By doing so, we promote public health, as stated in the curriculum. In this way, we can develop FH education for the $21^{\text {st }}$ century.

\section{References}

Afshin, A., John Sur, P., Fay, K. A., Cornaby, L., Ferrara, G., Salama, J. S., Mullany, E. C., Hassen Abate, K., Abbafati, C., Abebe, Z., Afarideh, M., Aggarwal, A., Agrawal, S., Akinyemiju, T., Alahdab, F., Bacha, U., Bachman, V. F., Badali, H., Badawi, A., ... Murray, C. J. L. (2019). Health effects of dietary risks in 195 countries, 1990-2017: A systematic analysis for the Global Burden of Disease 
Study 2017. The Lancet, 393, 1958-1972. https://doi.org/10.1016/So140-6736(19)30041-8 Askeland, N., Skjelbred, D., Aamotsbakken, B., \& Maagerø, E. (2017). Norsk loerebokhistorie [Norwegian textbook history]. Scandinavian University Press.

Beinert, C. (2021). "An unexploited potential" LifeLab Food and Health: Assessment and development of teaching and learning practices in the Norwegian school subject food and health (Doctoral dissertation). University of Agder. https:/uia.brage.unit.no/uia-xmlui/bitstream/ handle/1125o/273788o/Dissertation.pdf? sequence $=4 \&$ isAllowed $=y$ Beinert, C., Palojoki, P., Åbacka, G., Hardy-Johnson, P., Engeset, D., Hillesund, E. R., Ask, A. M. S., Øverby, N. C., \& Vik, F. N. (2020). The mismatch between teaching practices and curriculum goals in Norwegian Home Economics classes: A missed opportunity. Education Inquiry, 12(2), 183-201. https://doi.org/https://doi.org/10.1080/20004508.2020.1816677 Beinert, C., Palojoki, P., Åbacka, G. K., Øverby, N. C., \& Vik, F. N. (2021). “Is there any sugar in bread?” A qualitative video analysis of student activating learning tasks in Home Economics. Acta Didactica Norden, 15(1), 1-21. https://doi.org/10.5617/adno.8078

Burton, M., Riddell, L., \& Worsley, A. (2018). Food consumers' views of essential food knowledge and skills for all consumers. Health Education, 118(3), 277-288. https://doi.org/10.1108/HE-10-2017-0047 Caraher, M. (2019). Home economics - A personal reflection on 30 years of work, friendships and the future. Journal of the Home Economics Institute of Australia, 25(2).

Craigie, A. M., Lake, A. A., Kelly, S. A., Adamson, A. J., \& Mathers, J. C. (2011). Tracking of obesityrelated behaviours from childhood to adulthood: A systematic review. In Maturitas, 7o(3), 266-284) .https://doi.org/10.1016/j.maturitas.2011.08.005

Cruz, F., Ramos, E., Lopes, C., \& Araújo, J. (2018). Tracking of food and nutrient intake from adolescence into early adulthood. Nutrition, 55-56, 84-9o. https://doi.org/10.1016/j.nut.2018.02.015 Directorate for Education and Training. (2019a). Core curriculum - values and principles for primary and secondary education. https://www.udir.no/Udir/PrintPageAsPdfService. ashx?pdfld=150459\&lang=eng Directorate for Education and Training. (2019b). Lareplan i mat og helse [Curriculum for food and health]. https://data.udir.no/klo6/v201906/laereplaner-lk2o/MHEo1-02.pdf

Dumont, H., Istance, D., \& Benavides, F. (2012). How can the learning sciences inform the design of 21 st century learning environments? The nature of learning using research to inspire practice - practitioner guide. http://www.oecd.org/education/ceri/50300814.pdf Espeland, M., Arnesen, T. E., Grønsdal, I. A., Holthe, A., Sømoe, K., Wergedahl, H., \& Aadland, H. (2013). Skolefagsundersøkelsen 2011 [School subject survey 2011]. https://hvlopen.brage.unit.no/ hvlopen-xmlui/bitstream/handle/11250/152148/Rapport.pdf European Commission. (2014). EU Action Plan on Childhood Obesity 2014-2020. https:// ec.europa.eu/health/sites/health/files/nutrition_physical_activity/docs/childhoodobesity_ actionplan_2014_2020_en.pdf

Fackler, S., \& Malmberg, L. E. (2016). Teachers' self-efficacy in 14 OECD countries: Teacher, student group, school and leadership effects. Teaching and Teacher Education, 56, 185-195. https://doi. 
org/10.1016/j.tate.2016.03.002

Grosso, G., Mistretta, A., Turconi, G., Cena, H., Roggi, C., \& Galvano, F. (2013). Nutrition knowledge and other determinants of food intake and lifestyle habits in children and young adolescents living in a rural area of Sicily, South Italy. Public Health Nutrition, 16(10), 1827-1836. https://doi.org/10.1017/ S1368980012003965

Hansen Brooke, L., Myhre Borch, J., Johannesen Wetting, A. M., Paulsen Mohn, M., \& Andersen Frost, L. (2016). UNGKOST 3 Landsomfattende kostholdsundersøkelse blant elever i 4. og 8. klasse $i$ Norge, 2015 [UNGKOST 3 Nationwide dietary survey among pupils in the 4 th and 8 th grade in Norway, 2015]. https://www.fhi.no/globalassets/dokumenterfiler/rapporter/2017/ungkost-3-rapportblant-9-og-13-aringer_endeligversjon-12-01-17.pdf

Kay, K. (2015). 21st century skills: Why they matter, what they are, and how we get there. In J. A.

Bellanca \& R. S. Brandt (Eds.), 21st century skills: Rethinking how students learn (p. 375). Solution Tree Press. https://books.google.no/books?hl=no\&lr=\&id=aGYXBwAAQBAJ\&oi=fnd\&pg=PT7\&dq=21+ century+skills+rethinking+how+students+learn\&ots=wbfZx--Z1Q\&sig=7vGdksyeWdRpWG2p2XvZ QDZGx5M\&redir_esc=y\#v=onepage\&q\&f=false

Lassen, K. (2020). Skolekjøkkenets hemmeligheter: En kvalitativ studie om loerernes matlagingsundervisning på ungdomsskolekjøkkenet [Secrets of the school kitchen: A qualitative study of teachers cooking education in the lower secondary school kitchen]. (Doctoral dissertation). University of South-Eastern Norway.

Ministry of Health and Care Services. (2017). Norwegian National Action Plan for a Healthier Diet - an outline. Healthy diet, meal enjoyment and good health for everyone! https://www.regjeringen. no/contentassets/fab53cd681b247bfa8c03a3767c75e66/norwegian_national_action_plan_for_a_ healthier_diet_an_outline.pdf Norwegian Directorate of Health. (2011). Kostråd for å fremme folkehelsen og forebygge kroniske sykdommer [Dietary advice to promote public health and prevent chronic diseases]. https:// www.helsedirektoratet.no/rapporter/kostrad-for-a-fremme-folkehelsen-og-forebygge-kroniskesykdommer-metodologi-og-vitenskapelig-kunnskapsgrunnlag

Øvrebø, E. M. (2014). Knowledge and attitudes of adolescents regarding home economics in Tromsø, Norway. International Journal of Consumer Studies, 38(1), 2-11. https://doi.org/10.1111/ijcs.12043 Statistics Norway. (2020, December). Pupils in primary and lower secondary school - annually - SSB. https://www.ssb.no/en/utdanning/statistikker/utgrs

Taar, J. (2017). Interthinking in Estonian home economics education. (Doctoral dissertation).

University of Helsinki. https://helda.helsinki.fi/bitstream/handle/10138/228138/Interthi. pdf? sequence $=1$

Veka, I., Wergedahl, H., \& Holthe, A. (2018). Oppskriften - den skjulte læreplanen i mat og helse Sammendrag [The recipe - the hidden curriculum in the subject Food and Health]. Acta Didactica Norge, 12(3), 1-21.

Vik, F. N., Beinert, C., Palojoki, P., Hillesund, Elisabet Rudjord Engeset, D., Ask, A. S., Åbacka, G., \& Øverby, N. C. (2020). Differences in formal education among Norwegian Home Economics teachers. 
Journal of the International Society for Teacher Education, 24(2), 45-59.

Vygotsky, L. S. (1978). Mind in society the development of higher psychological processes. M. Cole, V. John-Steiner, S. Schribner, \& E. Souberman (Eds.), Harvard University Press.

Woods-Townsend, K., Bagust, L., Barker, M., Christodoulou, A., Davey, H., Godfrey, K., Grace, M., Griffiths, J., Hanson, M., \& Inskip, H. (2015). Engaging teenagers in improving their health behaviours and increasing their interest in science (Evaluation of LifeLab Southampton): Study protocol for a cluster randomized controlled trial. Trials, 16(1). https://doi.org/10.1186/s13063-015089o-Z

World Health Organization. (2006). Food and nutrition policy for schools - A tool for the development of school nutrition programmes in the European Region. https://www.euro.who.int/_data/assets/ pdf_file/oo19/152218/E89501.pdf

World Health Organization. (2015). European Food and Nutrition Action Plan 2015-2020. https:// www.euro.who.int/_data/assets/pdf_file/ooo3/294474/European-Food-Nutrition-Action-Plan20152020-en.pdf

\section{Biographical note}

Cecilie Beinert, PhD, is an assistant professor working at the Department of nutrition and public health at the University of Agder, Norway. Her main research interests are on Food and Health (Home Economics) in a public health perspective.

Nina Cecilie Øverby, $\mathrm{PhD}$, is a full professor in nutritional epidemiology working at the Department of nutrition and public health at the University of Agder, Norway. She is the leader of the Priority Research Centre on Lifecourse Nutrition.

Frøydis NordgårD Vik, PhD, is a full professor in the field of public health nutrition at the Department of nutrition and public health at the University of Agder, Norway. Her main research focus is school meals and interventions to promote lifecourse nutrition and sustainable diet from early ages to parenthood in relation to lifelong health. 